\title{
ENDOPARASITIC HELMINTHES OF THE STRIPED MULLET, MUGIL CEPHALUS, FROM THE NORTHERN RED SEA: EFFECT OF THE HOST'S MODE OF LIFE ON THE INCIDENCE AND INTENSITY OF INFECTION
}

\author{
Reda M. EI-Said Hassanine' and Ashraf I. Ahmed ${ }^{2}$ \\ 1-Department of Biology, New Valley Faculty of Education, \\ Assiut University, El-Kharga, New Valley, Egypt \\ 2- Marine Science Department, faculty of Science, Sucz Canal \\ University, Ismailia, Egypt
}

Key words: Digenean trematodes, Cestoda ${ }_{*}$ Acanthocephala, Mugil cephalus- incidence and intensity of infection- Red Sea.

\section{ABSTRACT}

\begin{abstract}
random sample of 267 individuals of the mullet Mugil cephalus, A was collected from the coasts of Sharm El-Sheikh, Northern Red Sea, Egypt. Examination revealed that 108 individuals with a general incidence of $40.44 \%$ were parasitized; of this number $63(23.59 \%)$ were parasitized by Lecithobotrys sprenti (Trematoda: Digenea: Haploporidae), 54 (20.22\%) by Carassotrema bengalense (Trematoda: Digenea: Haploporidae), $35(13.10 \%)$ by plerocercoid larvae (Cestoda: Tetraphyllidea), and 34 (12,73\%) by Heterosentis overstreeti (Acanthocephala: Arhythmacanthidae). These parasites are recorded, redescribed and figured for the first time from numerous specimens from the Red Sea to give broadened descriptions. However, the female acanthocephalan $H$. overstreeti is hereby described for the first time. The examined sample of $M$. cephalus were separated into three regular size groups. In each group, the incidence and intensity of each parasite were discussed. It was concluded that the incidence and intensity of parasites in marine fishes depend to a great extent on the host's mode of life.
\end{abstract}

\section{INTRODUCTION}

The striped mullet, Mugil cephalus has a circumglobal distribution, since it is widely distributed in the coastal waters, brackish waters, and estuaries of the tropical and subtropical zones. In 
many regions, the helminth parasites of this fish were comprehensively studied; in the Black Sea by Vlassenko (1931). Reshetnikova (1955) and Polyanski (1958); in the Mediterranean Sea by Papena (1964); in the Northern Gulf of Mexico by Overstreet (1971); in the Biscayne Bay, Florida by Skinner (1975) and in India by Rekharani and Madhavi (1985). Paperna and Overstreet (1981) gave a checklist of parasites recorded from mullets. Several regions remain to be explored. However, differences in the parasitic fauna of mullcts from widely separated areas are expected with the different geographical localities (Manter, 1955; Noble and Noble, 1971; Skinner, 1975; Rekharani and Madhavi, 1985).

Without exaggeration, the parasitic fauna of mullets inhabiting the Red Sca is little known in the literalure. Therefore, the present study aimed to examine a random sample of the striped mullet, Mugil cephalus, from the coasts of Sharm El-Sheikh, Northern Red Sea to identify its helminth parasites as well as the incidence and intensity of. infection.

\section{MATERIAL AND METHODS}

In May 2001,267 specimens of the fish Mugil cephalus ranging in size from 10.1 to $34.3 \mathrm{~cm}$ (total length), were collected as a random sample from the coasts of Sharm El-Sheikh, Northern Red Sea, Egypt. These specimens were separated into three size groups of regular length intervals (small, intermediate, and large group). Standard parasitological techniques were used to examine the different organs of fish. The number of parasitic worms was carefully recorded. The intensity of infection (mean/host) was estimated as the number of worms recovered per infected fish. Parasitic worms were removed from their host fishes under a dissecting microscope, kept alive in sea water diluted to $1 \%$ salinity as recommended by Schroeder (1971), and observed under a research compound microscope. The worms were fixed in alcohol-formalin-acetic (AFA) under slight coverslip pressure, and preserved in $70 \%$ ethyl alcohol. Whole mounts were stained by alum carmine, cleared in terpineol, and mounted in Canada balsan. Figures were drawn with the aid of a camera lucida. 


\section{RESULTS AND DISCUSSION}

Four different species of parasitic helminthes were collected from the examined sample of Mugil cephalus. The taxonomic position and the main characteristics of these species are as follows:

(Trematoda: Digenea)

Order: Prosostomata

Family: Haploporidae Nicoll , 1914

Lecithobotrys sprenti Martin, 1973

(Fig. 2 A)

Site of infection: intestine.

Description (based on numerous specimens):

The body is fusiform, covered with minute spines, and measures $0.805-1.150 \mathrm{~mm}$ long by $0.165-0.250 \mathrm{~mm}$ wide at its middle. The oral sucker is sub-terminal, spheroid, and measures $0.080-0.115 \mathrm{~mm}$ long by $0.085-0.120 \mathrm{~mm}$ wide. The acetabulum is spheroid, situated in the second fourth of the body, and measures $0.084-0.115 \mathrm{~mm}$ in diameter. Sucker ratio is about $1: 1$. The prepharynx is relatively long, and measures $0.056-0.075 \mathrm{~mm}$ in length. The pharynx is well developed, highly muscular, and measures $0.055-0.075 \mathrm{~mm}$ long by $0.068-0.095 \mathrm{~mm}$ wide. The oesophagus is 0.153-0.225 mm long, and bifurcates just behind the acetabulm into two short saccular intestinal caeca. The single testis is oval in shape, situated in the middle of the hindbody, and measures $0.085-0.115 \mathrm{~mm}$ long by $0.060-0.080 \mathrm{~mm}$ wide. The external seminal vesicle is present. The hermaphroditic pouch is relatively large, arched around the right border of the acetabulum, and measures $0.159-0.225 \mathrm{~mm}$ long by $0.080-0.105 \mathrm{~mm}$ wide. It contains a saccular internal seminal vesicle, a moderately developed prostatic complex, and a hermaphroditic duct leading into the genital pore, which lies between the acetabulum and pharynx. The ovary is relatively small, oval in shape, situated just behind the intestinal bifurcation, and measures $0.055-0.070 \mathrm{~mm}$ long by $0.040-0.050 \mathrm{~mm}$ wide. The uterine loops extend to near the posterior extremity; the terminal loop passes forwards and penetrates the hermaphroditic pouch to join the hermaphroditic duct. The vitelline follicles arranged in two 
symmetrical bunches, on each side of the ovary. A transverse vitelline duct arises from each bunch and opens into a swoilen vitelline rescrvoir situating behind the ovary. The eggs are operculated, oculate

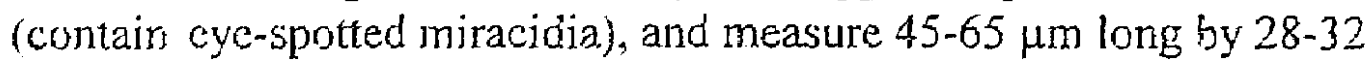
$\mu m$ wide. The excretory vesicle is saccular, and extends anteriorly to near the testis; the excretory pore is postero-terminal.

Nine species have so a been described in the genus Lecihhobotrys Looss, 1902 viz. L. putrescens Looss, 1902 (type species), I. vitellosus (Sharma and Gupta, 1970) L. sprenti Martin, 1973). L. maginovatus (Szidat, 1954 and Martin, 1973) L. maguns (Szidat, 1954) Martin, 1973, L. elongatus (Szidat, 1954) Nasir and (iomes, 1976) L. octuvus (Szidat, 1954 and Nasir \& Gomez, 1976, L. mugilis Reklarani \& Madhavi, 1985) and L. aegypliacus (Hassan et al. 1990 )

Most species of the genus Lecithobotrys and other genera of the family Ilaploporidac Nicoll, 1914 are usually parasitic in the intestine of mullets. Lecithobotrys sprenti was briefly described from 10 specimens collected by Martin (1973) from the intestine of Mugil cephalus in Australia. To date, no other information were published to mention this species. In the present study, L. sprenti was redescribed for first time from Mugil cephalus inhabiting the Northern Red Sea. However, the given redescription was based on pumerous specimens to give a broadoned description. Mugil cephalus and other species of mullets arc widely distributed in the coastai waters, brackish waters, and estuaries of tropical and subtropical zones, and capable of undertaking migrations from the sea into freshwater habitats. Therefore, Manter (1957) suggested that mullets act as "ecological bridges" in the initial dispersal of digenean trematods from marine fishes into freshwater hosts and vice versa. Lumsden (1963). Shireman (1964), Skinner (1975), and Rekharani and Madhavi (1985) provided evidence in fovour of Manter's ecological bridge theory.

Curassotrema bengalense Rekharani and Madhavi, 1985

(Fig. 2 B)

Site of infection: instestine.

Description (based on numerous specimens):

The body is fusiform, covered with minute spines, and measures $0.856-1.130 \mathrm{~mm}$ long by $0.288-0.360 \mathrm{~mm}$ wide. The oral sucker is well developed, sub-terninal, wider than long, and measures 
$0.075-0.100 \mathrm{~mm}$ long by $0.104-0.130 \mathrm{~mm}$ wide. The acetabulum is spherical, situated just pre-equatorial, and measures $0.124-0.160 \mathrm{~mm}$ in diameter. Sucker ratio is about 1: 1.19-1.23. The prepharynx is relatively long and measures $0.060-0.081 \mathrm{~mm}$ in length. The pharynx is globular, and measures $0.072-0.110 \mathrm{~mm}$ long by $0.072-0.094 \mathrm{~mm}$ wide. The oesophagus is relatively short measuring $0.065-0.083 \mathrm{~mm}$ in length, and bifurcates immediately in front of the acctabulum into two narrow instestinal caeca extending backwards to near the posterior extremity. The single testis is fairly large, elongate, slightly lobed, median, and measures $0.280-0.380 \mathrm{~mm}$ long by $0.128-0.170$ $\mathrm{mm}$ wide. The hermaphroditic pouch is short, extending between the acetablum and pharynx, and measures $0.102-0.130 \mathrm{~mm}$ long by 0.060-0.072 $\mathrm{mm}$ wide. It contains a saccular internal seminal vesicle, a short pars prostatica surrounded by few prostatic cells, and a hermaphroditic duct leading into the genital pore, which lies immediately behind the pharynx. The external seminal vesicle is present, situated behind the acetabulum, and connected to the internal seminal vesicle by a narrow tube. The ovary is oval, antero-lateral to the testis, and measures $0.104-0.140 \mathrm{~mm}$ long by $0.075-0.110 \mathrm{~mm}$ wide. The seminal receptacle is rounded and situated antero-lateral to the ovary. The uterus is thin-walled, very short, and composed of a single loop extending between the ovary and the hermaphroditic pouch; the distal portion of the uterus penetrates the hermaphroditic pouch to join the hermaphroditic duct. The vitelline follicles are irregular in shape, moderate in size, and extending in the lateral fields from the anterior border of acetabulum to near the posterior extremity. The eggs are fairly large, operculated, yellowish, few in number (13 /worm), and measure 80-95 $\mu \mathrm{m}$ long by 65-76 $\mu \mathrm{m}$ wide. The excretory vesicle is saccular, and extending anteriorly to near the posterior border of testis; the excretory pore is postero-terminal.

Nine species have so for been described in the genus Carassoterma Park, 1938 viz. C. koreanum Park, 1938 (type species), C. megapharyngus Wang, 1964, C. lemelorchis Wang, 1964, C. muglilcola Shireman, 1964, C. ginetzinskjae Kulkova, 1976, C. tilapiae Nasir and Gomez, 1976, C. kui Tang and Lin, 1979, C. estuarinum Tang and Lin, 1979, and C. bengalense Rekharani and Madhavi, 1985. Many of these species were recorded from mullets. 
Carasintrema beingalense sias brietjy described fion 5 ajpecimens collected by Reskerani and vadhavi (1985) from the incestine of Alugrl cephalus in India. To daid, no other intomation wert: publisilud to mention this species. In the present study. $C$. hengulens" was redescriber for the fires time from ifugil cephalus inhabiling the Iforthem Red Sea fowever, the given redescription

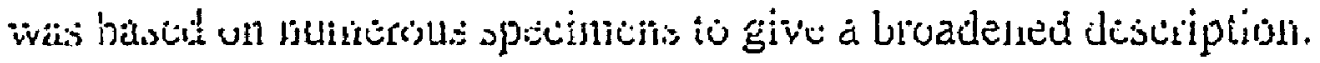
(Cestoda: Eucestoda)

(s)de): Tetraphyllidae

Plesocercoid liarvae

(Fig. 3)

Sile of infection: gall bladder.

Description (based on numerous specimens):

The body is elongate, somewhat flattened, and measures 1.72 . $2.64 \mathrm{~mm}$ long by $0.35-0.49 \mathrm{~mm}$ wide. The anterior end is provided wilh 4 bilocular suckers (without accessory suckers). Each sucker measures $0.13-0.17 \mathrm{~mm}$ in dianeter. The apical sucker is present and measures $0.055-10.073 \mathrm{~mm}$ in diameter. The posterior end of the body is bluncly rounded. A distinct water vascular system extending longitudinally from area immediately behind suckers to the posterior axtrunicy. Rod pigment patches presant behind suckers in all specimens.

Linton (1897, 1901) recorded and sketched larval cestodes from more than 60 widely differing species of fishes. He listed them under the collective name Scolex polymorphus Rudolphi. 1819. In a later report. Linton (1908) concluded that these larvae belong to a number of different cestode genera. Yamaguti (1934) accepted this view and distingtished the cestode larvae into 6 different types. The present cestode larvat conform closely to the characteristics of type IV (= plerocercoid larvale). These larvae are frequently referred to in the literaturc unde: the name Scolex polymorphs Rudolphi, 1981. Cestude larvae were recorded from Mugil cephalus in different lucalities: in the Black Sea by Dogiel (1956). in Istael by Paperna (1964), and itt Florida by Skinner (1975).

(Acanthoccphala: Paleacanthocephala)

Order: Echinorlyynchida

Family: Arbythmacanthidae Yamaguti. 1935

Heterosentis werstreti (Schmidt and Papena. 1978) Amin, 1985

(Fig. 4)

Site of infection: intestine. 
ENDOPARASITIC HELMINTHES OF THE STRIPED MULLET, 47 MUGIL CEPHALUS, FROM THE NORTHERN RED SEA

Description (based on numerous specimens):

The trunk is elongate, sub-cylindrical, spined, $8.10-12.10 \mathrm{~mm}$ long by $1.77-2.30 \mathrm{~mm}$ wide in males, and $9.10-13.50 \mathrm{~mm}$ long by $1.28-2.60 \mathrm{~mm}$ wide in females. Proboscis is spheroid, $1.17-2.21 \mathrm{~mm}$ in diameter in males, $1.85-2.36 \mathrm{~mm}$ in diameter in females, and armed with three types of sharp hooks arranged in 12 alternating longitudinal rows. Each row includes 4 hooks of variable lengths; apical hook 72 $90 \mu \mathrm{m}$, the next one 170-205 $\mu \mathrm{m}$, and the remaining two $49-65 \mu \mathrm{m}$ in length. The neck is relatively short, and measures $0.50-0.67 \mathrm{~mm}$ long by $0.70-1.15 \mathrm{~mm}$ wide at its base. Proboscis receptacle is cylindroid, double-walled, $1.17-2.21 \mathrm{~mm}$ long in males, and 1.92-2.41 mm long in females. The brain (rounded ganglion) lies in the middle region of the proboscis receptacle. Lemnisi are claviform, slightly longer than the proboscis receptacle being 1.84-2.62 $\mathrm{mm}$ long in inales, and 2.10 $2.95 \mathrm{~mm}$ long in females. The testes are oval in shape, tandem, and nearly situated in the middle of the body; the anterior testis is 1.20 $1.65 \mathrm{~mm}$ long by $1.38-1.85 \mathrm{~mm}$ wide, while the posterior testis is $1.40-1.81 \mathrm{~mm}$ long by $1.50-2.00 \mathrm{~mm}$ wide. Cement glands are six in number, tubular measuring 1.69-2.41 mm long, and lead into a saccular cement reservoir. The ejaculatory duct is tubular, and opens into a cylindrical protrusible penis measuring $0.93-1.30 \mathrm{~mm}$ long. Copulatory bursa well developed, hemispheric, and measures 0.85 $1.11 \mathrm{~mm}$ in diameter. The ovarian balls are relatively large in size, and distributed in most of the pseudocoel. The uterine bell is well developed, its base lies at 2.55-3.55 $\mathrm{mm}$ from the genital opening. The uterus is tubular, and leading posteriorly into a well-developed vagina surrounded by a sphincter muscle on each side.

Based on a single male specimen, Schmidt and Paperna (1978) described Arhythmacanthus overstreeti as a new acanthocephalan species from the intestine of Silhouettea insinuans, a fish from Gulf of Elat, Israel. Accordingly, the given description was inadequate and nothing was mentioned about the characteristics of the female. Amin (1985) transferred this species to the genus Heterosentis Van Cleave, 1931 as H. overstreeti (Schmidt and Paperna, 1978) Amin, 1985. To data, no other information were published to mention this species. In the present study, the female of $H$. overstreeti was described and figured for the first time, while the male is redescribed from numerous specimens to give a broadened description. However, the 
fish Mugil cephalus is considered as a new host record for this parasite from the Red Sea.

\section{Incidence and intensity of infection:}

Out of 267 Mugil cephalus examined, 108 individuals with a general incidence of $40.44 \%$ were found parasitized; of this number $63(23.59 \%)$ were parasitized by Lecithobotrys sprenti, $54(20.22 \%)$ by Carassotrema bengalense, $35(13.10 \%)$ by plerocercoid larvae, and $34(12.73 \%)$ by Heterosentis overstreeti. The incidence and intensity of each parasite in the different size group of $M$. cephalus are recorded in Table (1). In the smaller size group, the infection with both the digenean trematodes and acanthocephalans was completely absent, while the incidence and intensity of infection with plerocercoid larvae of cestodes were relatively high. In the intermediate size group, the infection with the digenean trematodes $L$. sprenti and $C$. bengalense, and with the acanthocephalan $H$. overstreeti started to appear with moderate incidence and intensity, while the incidence and intensity of plerocercoid larvae were very scarce in this group. In the larger size group, the incilence and intensity of infection with digenean trematodes and acanthocephalans werc relatively high, while the infection with plerocercoid larvac of cestodes was completely absent in. According to Broadhead (1953) and Odum (1966), the life history of Mugil cephalus is distinguished into two distinct phases; the pelagic life of the young fish feeding on planklonic crustaceans, and the inshore life of the adults feeding on detritus. By using these information, the present results can be explained, since individuals of the smaller group of $M$. cephalus act as intermediate hosts for many species of marine cestodes. Accordingly, the incidence and intensity of plerocercoid larvae were relatively high in this group, while the infection with both the digenean trematodes and acanthocephalans was completely absent. Individuals of the intermediate size group are known to feed on algae and the bottom scum, on which the cercariae of the present digenean trematodes (haploporid cercariae) usually encyst (Rekharani and Madhavi, 1985), also adult mullets feed on benthic crustaceans (intermediate hosts of acanthocephalans) that get entangled in the bottom. Accordingly, the incidence and intensity of digenean trematodes and acanthocephalans were moderate in this group, while thosc of the plerocercoid larvae were very scarce. Individuals of the larger size group are bottom feeding on detritus so, the infection with 
plerocercoid barvae was completely absent in this group, while the incidence and intensity of infection with digenean trematodes and acanthocephalan were relatively high. To explain a nearly similar result, Kennedy (1975), Priemer (1979), and Noble and Noble (1982) believed that chances of certain parasitism may be greater for large hosts, which have greater surface area, consume more potentially parasite-laden food, and have lived longer than the small individuals.

In the present area of study, Mugil cephalus served as a definitive host for the digenean trematodes Lecithobotrys sprenti and Carassotrema bengalense, and for the acanthocephalan Heterosentis overstreeti. Also, it served as an intermediate host for plerocercoid larvae of cestodes. These larvae can be termed as "childhood parasites", since they become scarcer or disappear with increasing the fish maturity due to a change in the mode of life.

Generally, the above results support Lom's (1970) and Skinner's (1975) openions that the incidence and intensity of parasites in marine fishes depend to a great extent on the host's mode of life.

\section{REFERENCES}

Amin, O. M. (1985). Classification of Acanthocephala. In Crompton, D. W. T. and B. B. Nickol (Eds.). Biology of the Acanthocephala. Cambridge Univ. Press, 512 pp.

Broadhead, G. C. (1953). Investigation of the black mullet, Mugil cephalus L., in Northwest Florida. Tech. Ser. Flo. St. Bd. Cons., 7: 1-34.

Dogiel, V. A. (1958). Ecology of parasites of freshwater fishes. In Dogiel, V. A.; Petrushevski, G. K. and Polyanski, Y. I. (Eds). Leningrad Univ. Press, $384 \mathrm{pp}$.

Hassan, S. H.; K, A. A. and ABU- S, O. A. (1990). Four trematodes from marine of fishes in Egypt. J. Egypt. Ger. Soc. Zool., 2: $63-74$.

Kennedy, C. R. (1975). Ecological Animal Parasitology. Blackwell Scientific Publications, Oxford, London, Edinburgh and Melbourne, $474 \mathrm{pp}$. 
Linton, E. (1897). Notes on larval cestode parasites of fishes. Proc. U. S. Nat. Mus., 19: 787-824.

Linton, E. (1901). Parasites of fishes of the woods Hole region. Bull. U. S. Fish Comm., 19: 405-492.

Looss, A. (1902). Die Distomen-Unterfamilie der Haploporinae. Arch. Parasitol., 6: 129-143.

Lumisden, R. H. (1963). Saccocoelioides sogandaresi sp. nov., a new haploporid trematode from the sailfin moll, Mollienesia latipinna La sueur in Texas. J. Parasitol., 49: 281-284.

Manter. H. W. (1957). Host specificity and other host relationships among digenetic trematodes of marine fishes. In first symposium on host specificity among parasites of vertebrates. Instit. Zool. Univ. Neuchatel., I: 185-196.

Martin, W. E. (1973). Life history of Saccocoeliodies pearsoni sp. nov., and the description of Lecithobotrys sprenti n.sp. (Trematoda: Haploporidae). Trans. Amer. Microscop. Soc., 92: 80-95.

Nas, P. and Gom, Y. (1976). Carassotrema tilapiae n. sp. (Haploporidae Nicoll, 1914) from the freshwater fish Tilapia mossambica in Venzuela. Riv. Parassitol., 37: 207-228.

Nicoll, W. (1914). Trematode parasites of fishes in the English Channel. J. Mar. Biol. Assoc. U. K. N. S., 10: 466-505.

NOBLE, E. R., and NOBLE, G. A. (1982), Parasitology. Philadelphia: Lea \& Febiger, $617 \mathrm{pp}$.

Odum, W. S. (1966). The food and feeding of the striped mullet, Mugil cephalus (L.) in relation to the environment. M. SC. Thesis, Univ. Miami, 310 pp.

Overstreet, R. M. (1971). Some adult digenetic trematodes in striped mullet from Northern Gulf of Mexico. J. Parasitol., 57: $967-$ 974. 
ENDOPARASITIC HELMINTHES OF THE STRIPED MULLET, 51 MUGIL CEPHALUS, FROM THE NORTHERN RED SEA

Paperna, I. (1964). The metazoan parasite fauna of Isracl inland water fishes. Bamidgeh. Bull. Fish Cult. Israel, 16: 3-66.

PAPERNA, I. and Overstreet, R. M. (1981). Parasites and diseases of mullets (Mugilidae) from aquaculture of grey mullets. Editor O. H. Oren, International Biological Programme 26, Cambridge Univ. Press.

Park, J. T. (1938). A new fish trematode with a single testis from Korea . Keijo J. Med., 9: 290-298.

Polyanski, Y. I. (1958). Ecology of parasites of marine fishes. In Dogiel, V. A. G. K. Petrushevski and Y. I. Polyanski (Eds). Parasitology of fishes. Leningrad Univ. Press, 384 pp.

Priemer, J. V. (1979). Darm-helminthen von Perca fuviatilis (L.) und Acerina cernura (L.) (pisces) aus Gewassern des Bertiner Randgebietes. Zool. Anz. Bd., 203: 241-251.

REKHARANI, Z., and Madhavi, R. (1985). Digenetic trematodes from mullets of Visakhapatnam (India). J. Nat. Hist., 19: 929-951.

RESHETNIKOVA, A. V. (1955). Parasite fauna of Mugil cephalus in the Black Sea. Tr. Karndah nauch stn. B., 2: 71-95.

SCHMIDT, G. D., and Paperna, 1. (1978). Selerocollum rubrimaris gen. et sp. n. (Rhadinorlynchidae: Gorgorhynchinae), and other Acanthocephala of marine fishes from Israel. J. Parasitol., 64: 846-850.

Schroeder, R. E. (1971). Ecology of the intestinal trematodes of the grey snapper, Lutijanus griseus, near Lower Matecumbe Key Florida, with a description of a new species. Stud. Trop. Oceanogr. Miami, 10: 151-221.

Sharma, P. N., and Gupta, A. N. (1970). Lecithobotrys vitellosus sp. nov.(Haploporidae Trematoda) from India. Rev. Parassitol., 31: 175-178. 
Shiremen, J. V. (1964). Carassotrema mugilicola, a new hoploporid trematode from the striped mullet, Mugil cephalus in Louisiana. J. Parasitol, 50: 555-556.

Skinner, R. (1975). Parasites of the striped mullet, Mugil cephalus from Biscayne Bay, Florida, with description of a new genus and three new species of Trematoda. Bull. Mar. Sci., 25: 318-345.

Szidat, L. (1954). Trematodos nuevos de peces de aquadulce de la republica Argentina y un intento para aclarar su caracter marine. Rev. Inst . Nac. Inv. Cienc. Nat. y museo argentino, 3: $1-85$.

Tang, Z.., AND LIN, X. (1979). Studies on Carassotrema Park, 1938, life-histories and distribution. Xiamen Daxye x Yubao, 1:8198.

Van Cleave, H. J. (1931). New Acanthocephala from fishes of Mississippi and a taxonomic reconsideration of forms with unusual number of cement glands. Trans. Amer. Microscop. Soc., 50: 348-363.

Vlassenko, P. V. (1931). Zur Heiminthofauna de Schwarzmeer-fische. Trud. Karadash. Nauch. Stant., 4: 88-136.

Yamaguti, S. (1934). Studies on the helminth fauna of Japan. Part 4. Cestodes of fishes. Jap. J. Zool., 6: 1-112. 
ENDOPARASITIC HELMINTHES OF THE STRIPED MULLET, MUGIL CEPHALIS, FROM THE NORTHERN RED SEA.

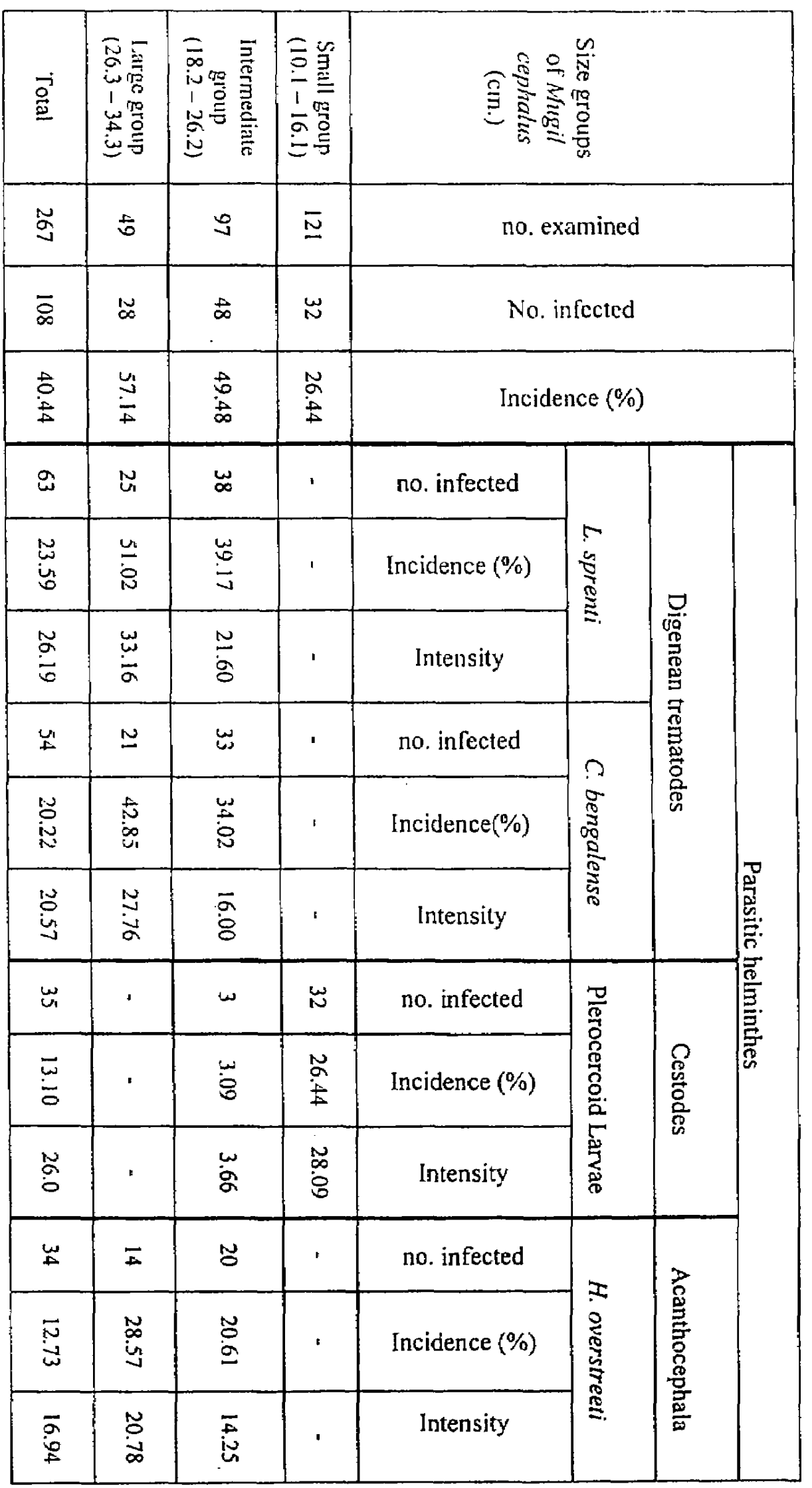

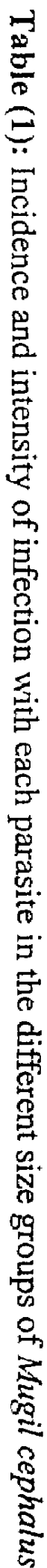




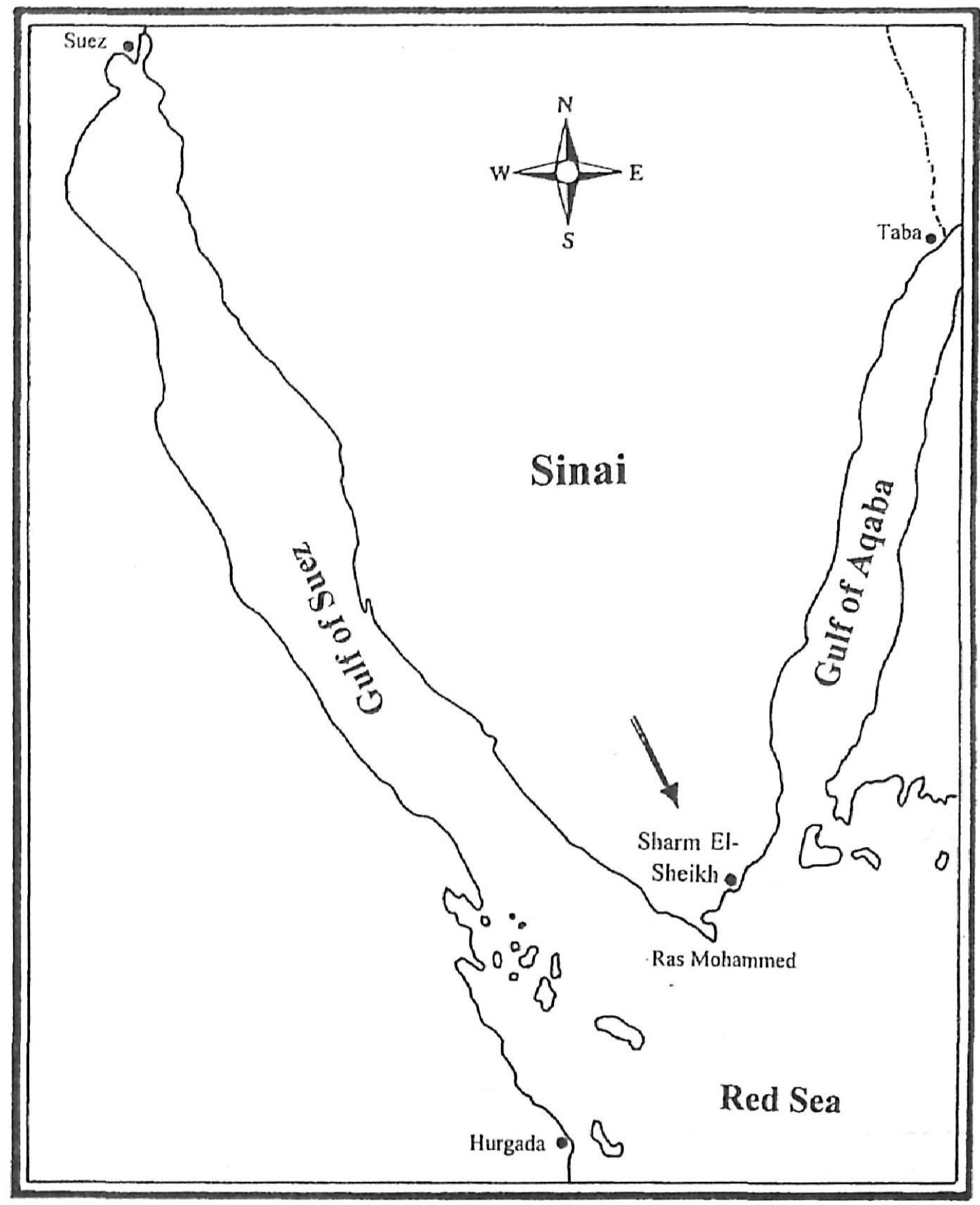

Fig. (1): A map showing the locality of the examined fishes . 


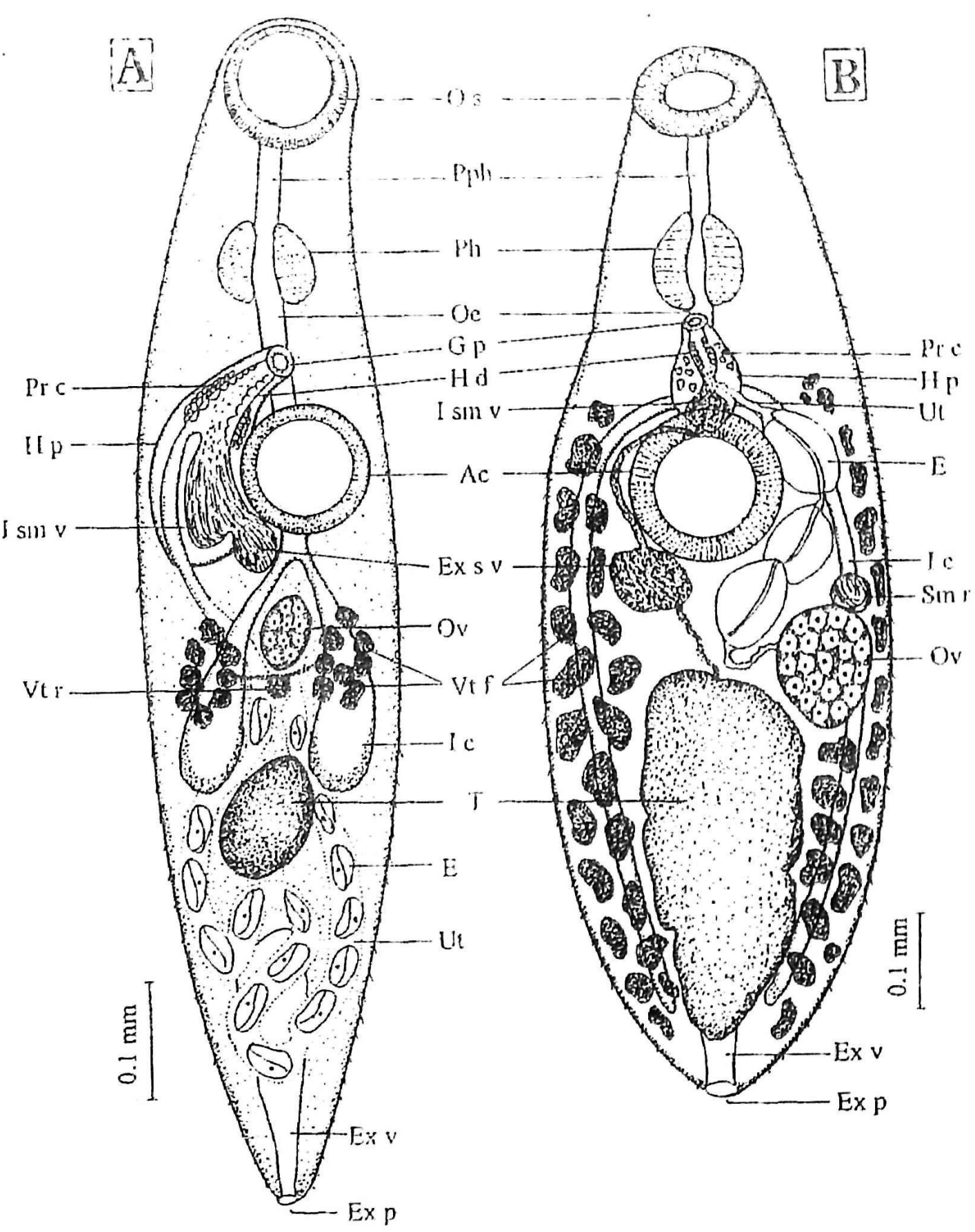

Fig.(2): A) Lecirhoborrys sprenti Martin, 1973.

B) Carassotrema bengalense Rekharani \& Madhavi, 1985. $A c=$ Acetabulum, E $=$ Egg, Ex $p=$ Excretory pore, Ex s $v=$ External seminal vesicle, Ex $v=$ Excretory vesicle, $G \mathrm{p}=$ Genital pore, $\mathrm{H} \mathrm{d}=$ Hermaphroditic duct, $\mathrm{H} \quad \mathrm{P}=$ Hermaphroditic pouch, I $\mathrm{c}=$ Intestinal caecum, I $\operatorname{sm} \mathrm{v}=\operatorname{Internal}$ seminal vesicle, De $=$ Desophagus, D $s=$ Dral sucker, $\mathrm{Ov}^{=}=$Ovary, $\mathrm{Ph}=$ Pharynx, $\mathrm{Pph}=$ Preplarynx, $\operatorname{Pr} c=$ Proslatic complex, Sm $r=$ Seminal receplacie: $T=T e s t i s, 1 t=$ Uterus, $V_{t} f=$ Vitelline follicles, $V_{t} r=$ Vitelline reservisir. 


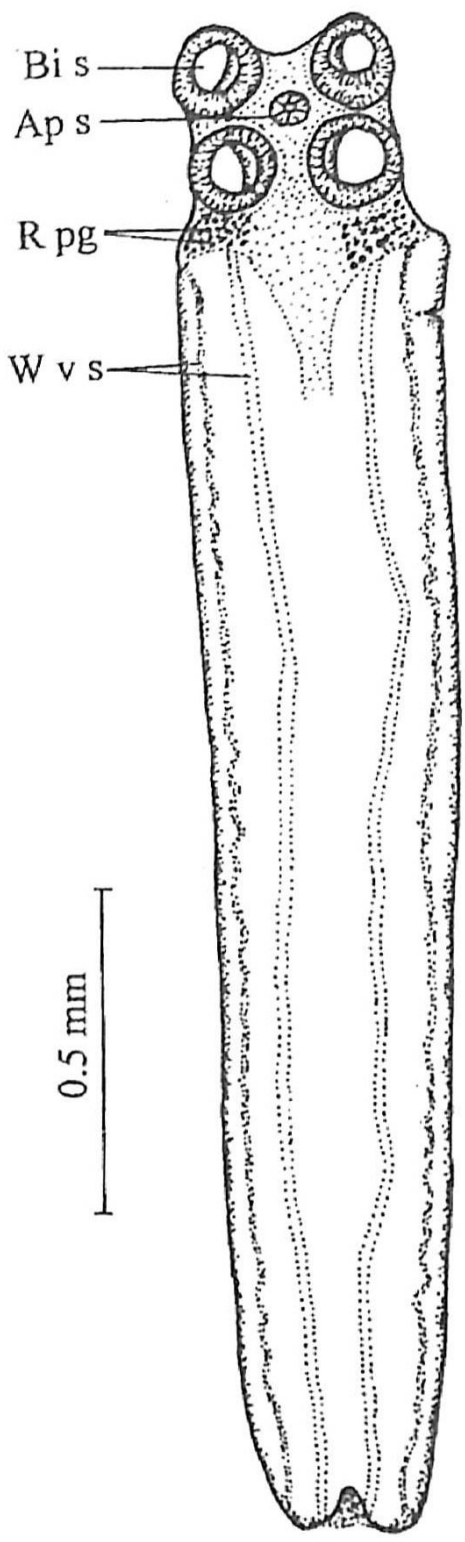

Fig.(3): Plerocercoid larva Yamaguti, 1934. Ap $\mathrm{s}=$ Apical sucker, $\mathrm{Bi} \mathrm{s}=$ Bilocular sucker, $\mathrm{R} p \mathrm{~g}=$ Red pigments, $\mathrm{W}$ v $\mathrm{s}=$ Water vascular system . 


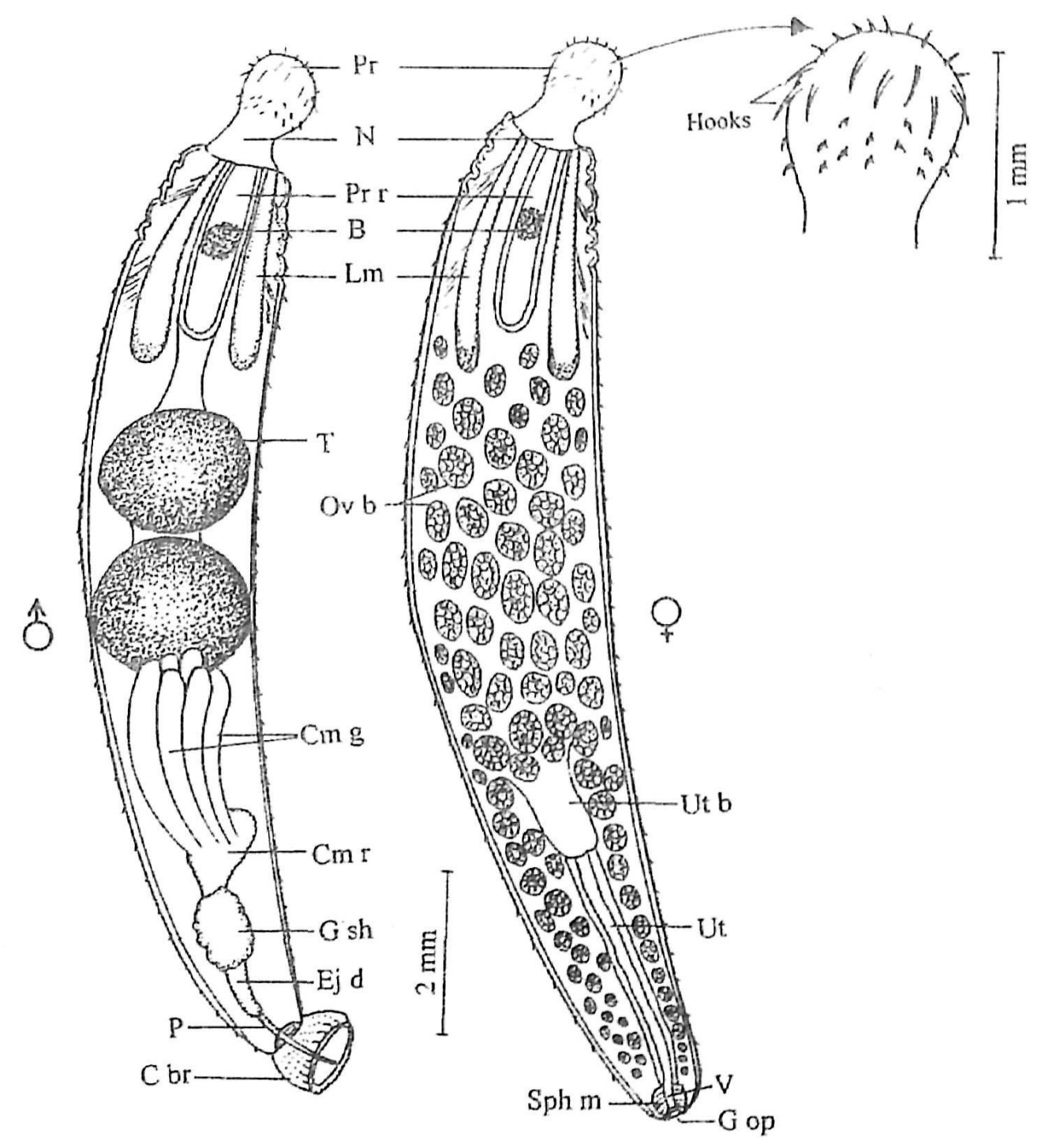

Fig.(4): Heterosentis overstreeti (Schmidt\&Paperna, 1978) Amin, 1985.

$\mathrm{B}=$ Brain, $\mathrm{C}$ br= Copulatory bursa, $\mathrm{Cm} \mathrm{g}=$ Cement glands, $\mathrm{Cm} r=$ Cement reservoir, Ej $d=$ Ejaculatory duct, $G$ op $=$ Genital opening, $G$ sh $=$ Genital sheath, $L m=$ Lemniscus, $N=$ Neck, Ov $b=$ Ovarian balls, $P=$ Penis, $P r=$ Proboscis, $\operatorname{Pr}=$ Proboscis receptacle, $S p h m=S$ phincter muscie, $T=T e s t i s$, $\mathrm{U} t=$ Uterus, Ut $\mathrm{b}=$ Uterine bell. $\mathrm{V}=$ Vagina. 